\title{
Semantika eta kognizioa
}

\author{
RAY JACKENDOFF \\ «Semantics and Cognition». 1996. In Shalom Lappin (arg.), \\ The Handbook of Contemporary Semantic Theory, Oxford: Blackwell: 539-559.
}

Itzultzailea: Larraitz Zubeldia ${ }^{1}$

DOI: $10.1387 /$ gogoa.19743

\section{I-semantikaren oinarrizko ikuspegia}

Chomskyk (1986) bi era bereizten ditu hizkuntza ikergai gisa lantzeko. «Kanpoko hizkuntzaren» edo E-hizkuntzaren azterketak gizakiek erabiltzen duten kanpoko tresna gisa hartzen du hizkuntza, eta haren propietateak kanpoko munduaren parte gisa ezaugarritzen saiatzen da; kanpoko munduarekin interakzioan dago gizakia. «Barneko hizkuntzaren» edo I-hizkuntzaren azterketak, berriz, hiztunen gogo/garuneko ezagutzaren zati gisa hartzen du hizkuntza, eta haren propietateak psikologiaren teoria orokorrago baten testuinguruaren baitan ezaugarritzen saiatzen da. Aspects of the Theory of Syntaxen (1965) garaiaz geroztik, gutxienez, I-hizkuntzaren azalpena ematea izan da esplizituki gramatika sortzailearen helburua.

Argi dago, gizakiek kanpoko munduan hizkuntza benetan nola erabiltzen duten azaltzeak hizkuntzaren printzipioak nola ulertzen dituzten azaltzea eskatzen du, azken batean; hau da, I-hizkuntzaren teoria bat. Hortaz, I-hizkuntzaren teoria bat beharrezkoa da azkenean, inork E-hizkuntzaren azalpena ere eman nahi izan edo ez. (Hain zuzen, Chomskyk argudiatu du gehiago ere, E-hizkuntza ez dela inola ere ikerketa zientifikorako baliagarri den gaia).

\footnotetext{
${ }^{1}$ Gogoatik eskerrak eman nahi dizkiogu Ray Jackendoffi, bere testua euskarara itzultzeko baimena eman digulako, eskatu eta berehala; adeitasunez. Horrez gain, itzultzaileak eskerrak eman nahi dizkie Joana Garmendia eta Kepa Kortari, testua zuzendu eta sortutako zalantzak argitzeagatik. Baita Xabier Arrazola eta Pello Huiziri ere, hurrenez hurren, logikako eta psikologiako hainbat terminoren gaineko argibideak emateagatik. Noski, itzultzailea da ezein akatsen erantzule. Itzulpen honen lehenagoko bertsioa hemen argitaratu zen, 2004an: Gogoa IV (2): 229-251.
} 
Dualtasun bera jasaten du semantikak, hizkuntzaren eta munduaren arteko harremanaren teoriak: batek azter dezake edo hizkuntzaren erabiltzaileengandik kanpoko harreman abstraktu gisa (E-semantika), edo hizkuntzaren erabiltzailearen gogo/garunaren baitako ezagutzaren zati gisa (Isemantika). Berriro ere gizakiek hizkuntza nola erabiltzen duten azaltzeak eskatzen du hizkuntzaren eta munduaren arteko harremana nola ulertzen duten azaltzea; beraz, azken batean, komenigarria da I-semantikaren teoria.

Zehazkiago, sintaxiaren eta fonologiaren teoriak I-hizkuntzaren jarreraren baitan badaude, teoria semantikoa arduratzen da edo hizkuntzaren erabiltzaileek hizkuntzari buruz duten ezagutzaren eta kanpoko munduaren arteko harremanaz («erdi-E-semantika» esango diot horri), edo hizkuntzaren erabiltzaileek hizkuntzari buruz duten ezagutzaren eta horiek mundua ulertzearen arteko harremanaz. Azken kasu horretan, teoria oso batek, hortaz, eskatzen du, baita ere, munduaren eta hizkuntzaren erabiltzaileek hura ulertzearen arteko harremana azaltzea; «pertzepzioa eta kognizioa» ohiko gaiaren baitan sartzen da harreman hori. 20.1 irudiak eskematizatzen du hurbiltze desberdin horien arteko harremana.

Semantikako ikerketa gehienak edo ez du esplizituki azaltzen bere jarrera, edo E-semantika aldarrikatzen du. Hala ere, I-semantikaren ikuspegia hartu du esplizituki hainbat tradizio independente samarretako gero eta lan gehiagok; giza hizkuntzaren eta giza kontzeptuen arteko harremana aztertzea dute helburu, eta hizkuntza erabiltzea giza kognizioaren egitura aztertzeko tresna gisa. Jarrera hori hartzearen ondorioak eta sortutako emaitza eta eztabaida nagusietako batzuk eztabaidatzen ditu oraingo kapituluak.

20.1 irudia

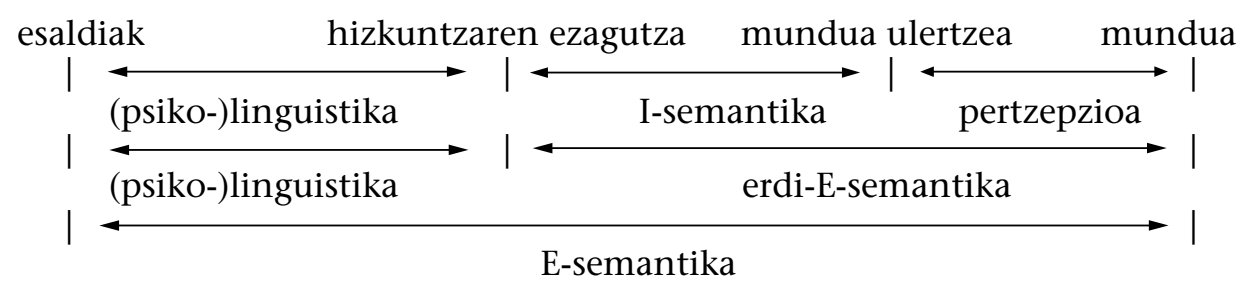

\section{I-semantikaren oinarrizko auziak}

Hona hemen I-semantikaren teoriarentzako oinarrizko galdera batzuk:

(1) Esanahiaren izaera

a. Zer eratan ulertzen dute gizakiek mundua? Hau da, zein dira giza kontzeptu/pentsamendu/ideien propietate formalak eta substantiboak?

b. Nola formaliza daitezke propietate horiek teoria erabat esplizitua eta prediktiboa garatzeko? 


\section{(2) Hizkuntzarekiko korrespondentzia}

a. Gizakiek mundua ulertzeko moduak nola daude hizkuntz adierazpenekin erlazionatuta sistematikoki?

b. Zer eratan, baten bat baldin bada, ez daude modu horiek hizkuntz adierazpenekin erlazionatuta sistematikoki, ezagutza ez-linguistikoaren, testuinguruaren, eta abarren eraginpean egonda? $\mathrm{Ba}$ al da banaketa naturalik faktore linguistiko eta ez-linguistikoen artean?

(3) Munduarekiko korrespondentzia

a. Gizakiek mundua ulertzeko moduak nola daude munduarekin berarekin erlazionatuta sistematikoki pertzepzio-sistemen bidez?

b. Zer eratan, baten bat baldin bada, ez daude modu horiek mundu fisikoarekin erlazionatuta sistematikoki? Hau da, zenbateraino dira abstraktuak giza kontzeptu/pentsamendu/ideiak?

E-semantikatik ezagunak diren auzien parekoak dira horiek. (1) dagokio hizkuntza naturaleko perpaus guztiak adierazteko egokia den hizkuntza intentsional bat sortzeko arazo formalari; propietate semantikoak (adibidez, esanahi-berdintasuna eta -desberdintasuna, inferentzia eta aurresuposizioa) perpausen arteko harreman formal gisa kalkulatu ahal izateko punturaino. (2) dagokio egitura sintaktikoa hizkuntza intentsional horretan aplikatzearen arazoari. (3) dagokie gutxi gorabehera erreferentziaren arazoari (hizkuntza intentsionala eredu batean aplikatzeari) eta hizkuntz adierazpenen intentzionalitatearen arazoari; nahiz eta, orain ikusiko dugun bezala, antzekotasuna azalekoa bakarrik den.

Baina, gainera, I-semantikan uste denez (1)-(3)n ikertutako teoria formalak giza garunean irudikatuta daudela, badira E-semantikarekin partekatzen ez diren funtsezko auzi batzuk.

(4) Garunean irudikatzea

a. Nola daude konektatuta garunean (1)-(3)ko sistemak, bai lokalizazio zabalari eta bai konexio neural lokalari dagokionez?

b. Zenbateraino dira sistema horiek garun-sistemen eredu osotasunean?

(5) Garapenari buruzko galderak

a. Pertsona batek nola bereganatzen ditu mundua ulertzeko dituen moduak eta modu horiek hizkuntz adierazpenekin eta pertzepzio -inputarekin erlazionatzen dituzten sistemak?

b. Zenbateraino da askea kontzeptuez jabetzea inguruari egokitzeko, eta zenbateraino gidatzen dute genetikoki ezarritako mugek, banakoen nahiz espezieen mailan? 
(6) Eboluzioari buruzko galderak

a. Gizakiak mundua ulertzeko duen moduaren zein alderdiren arrastoa jarrai daiteke aurrekari ez-gizatiarretaraino, eta zeinek islatzen dituzte berrikuntza ebolutiboak?

b. Berrikuntza horiek zenbateraino islatzen dute berrikuntza ebolutiboa osotasunean?

Esan nahi baita I-semantika, E-semantika ez bezala, psikologiako, neurozientziako eta biologiako gai orokorrago batzuei lotzen zaie, hasiera batean. Nahiz eta horrelako loturak hastapenetan diren, lotura horiek ezartzeko nahiak muga-baldintzak jartzen dizkio, ikusiko dugun bezala, ikerketa tradizioko teoria semantikoaz nahikoa bestelako norabideetan bultzatzen duen eginkizunari.

Kontuan hartu beharko litzateke, baita ere, (4)-(6)ko galderak hizkuntzalaritza sortzailean oso ezagun diren auzien parekoak direla bete-betean, hark I-hizkuntzan jartzen baitu arreta. Desberdintasun interesgarri bat da ilun samarrak izateko joera dutela hizkuntzari buruzko eboluzio-galderek, hizkuntza per se gizakietan besterik ez baitago frogatuta. Aldiz, gizakiak mundua ulertzearen hainbat alderdik animalia-parekotasun nabarmenak dituzte; horregatik, eboluzio-auziek zeregin interesgarria izan dezakete teoria eraikitzean.

\section{Erreferentzia batzuk ${ }^{2}$}

Gramatika sortzailearen baitako semantikako hasierako lan batzuek aitortu zituzten, neurri batean, helburu horiek. Katz eta Fodorrek (1963), Katzek (1972) eta Weinreichek (1966) giza gaitasunaren gaian kokatzen dute teoria semantikoa, baina ez diete heltzen (4)-(6) gisako gaiei. Bierwisch $(1967,1969)$ ezohikoa da, esplizituki lotzen baitu primitibo semantikoak eta unibertsal semantikoak bilatzea pertzepzio-psikologiarekin.

1970eko urteetan semantika eta kognizioa lotzen saiatzen ziren lan asko garatu ziren. Fodor, Bever eta Garrettek (1974) eta bereziki Fodorrek (1975) molde psikologikoan kokatu zituzten esanahiari buruzko ohiko gai filosofikoak. Miller eta Johnson-Lairdek (1976) esanahi lexikalaren azalpen oso handia garatu dute esplizitutasun konputazionala eta egiantza psikologikoa bilatzen dituen egitura batean. Jackendoff $(1976,1978)$ gramatika-ereduen eta horiek adierazten dituzten egitura kognitiboen arteko harremanaz ari da. AAren tradizioaren baitan, Schanken (1973) «mendekotasun kontzeptualak»,

2 Behean bildutako zerrenda nik egindako aukera da ezinbestean. Barkamena eskatzen dut aurrez, irakurleak funtsezkotzat jotzen duen lanen bat ez aipatzeagatik egindako ezein hutsengatik. 
Minskyren (1975) «egiturak» eta Schank eta Abelsonen (1975) «gidoiak», guztiak jotzen dira esplizituki hizkuntzaren eta giza kontzeptuen arteko loturaren teoriatzat.

Rosch izan zen aitzindari (Rosch 1973, 1975, 1978; Rosch eta Mervis 1975; Rosch eta beste 1976) hitzen esanahien izaera erakusten duten esperimentu psikologikoak egiten; zalantzan jarri zituzten teoria klasikoak. Berlin eta Kay (1969), Clark eta Chase (1972) eta Levelt (1984) dira aipatzea merezi duten garai horretako beste lan batzuk.

Haurren garatze semantikoari buruzko ikerketa esperimentala eta teorikoa ere garai hartan hasi zen garatzen. Lan garrantzitsuenen artean dira Brown (1973), E. Clark (1973), H. Clark (1973), Bowerman (1974, 1978, 1989), Katz, Baker eta Macnamara (1974), Keil (1979), eta, pixka bat geroago, Macnamara (1982, 1986), Landau eta Gleitman (1985), Carey (1985), Pinker (1984, 1989), Keil (1989), Markman (1989) eta Bloom (1994).

Berrikiago, hizkuntzalaritzako bi eskola nagusi bereiz daitezke, oro har, esanahia giza kontzeptuekin identifikatzea dutenak printzipio nagusitzat. Hizkuntzalaritza kognitiboa edo Gramatika kognitiboa da bata, gramatika sortzailetik independentea dena (kasu askotan, berariaz). Lakoff $(1987,1990)$, Lakoff eta Johnson (1980), Lakoff eta Turner (1989), Langacker $(1987,1991)$ eta Talmy $(1978,1980,1983,1985)$ dira mugimendu horretan ezagunenak; beste lan garrantzitsu batzuk dira Brugman (1981), Fillmore (1982), Fauconnier (1985), Herskovits (1986), Levinson (1992) eta Vandeloise (1986). Beste eskola I-semantikaren teoria gramatika sortzailearen egitura sintaktikoarekin integratzen saiatzen da. Honako hauek dira ikuspegi horren erakusle esanguratsuenetako batzuk: Jackendoff $(1983,1987,1990,1992)$ (Semantika kontzeptuala esaten dio eginkizunari), Bierwisch (1981, 1982), Bierwisch eta Lang (1989), Pinker (1989), Nikanne (1990) eta Pustejovsky (1991). Zwarts eta Verkuylek (1994) eredu-teoriaren arabera berrantolatzen dute Jackendoffen hurbiltzea. Wierzbickarena $(1980,1985,1987,1988)$ da beste hurbiltze independente bat.

Kapitulu honetako gainerako eztabaidak, joera horien ideiak banan-banan landu partez, I-semantika osotasunean hartuta egindako ikerketen gaietan eta ondorioetan jartzen du arreta; etorri ahala aipatuko dira hurbiltzeen arteko adostasunak eta desberdintasunak.

\section{Egiaren eta erreferentziaren izaera I-semantikan - Atarikoak}

Semantika giza organismoaren egiturari buruzko gai gisa hartzeko, beharrezkoa da eginkizunaren oinarrizko helburuekin zuhur jokatzea. Bereziki, berriz ebaluatu beharra dago perpaus baten egiaren edo faltsutasunaren nozioa azaltzeko izan den ohiko kezka. Izan ere, jada ez dago esaldiaren eta 
munduaren arteko erlazio zuzenik, esaldia egiazko edo faltsu egiten duena; aitzitik, hiru erlazioko segida dago, 20.1 irudiko diagraman goiko lerroan azaltzen dena.

Ondorioz, I-hizkuntzalaritzarentzako gramatikaltasunaren definizioaren parekoa da I-semantikarentzako egiaren definizioa. I-hizkuntzalaritzan, (7a) baiezpena, hiztuna kontuan hartu gabeko perpausei buruzkoa dirudiena, (7b) baiezpenaren laburdura gisa hartzen da beti; (7b)k hizkuntza-erabiltzailearen gogoan jartzen du zuzenean gramatikaltasuna.

(7) a. $K$ katea $H$ hizkuntzako perpaus gramatikala da.

b. $H$ hizkuntzako hiztun batek gramatikaltzat jotzen du $K$ katea (oroimen- eta prozesatze-mugen arabera, eta hiztunen arteko uniformetasun-idealizazio baten pean).

Orobat, (8a) egiaren ohiko tarskiar definizioa judizio-gai gisa berrinterpretatu behar da I-semantikan, (8b)n bezala.

(8) a. $H$ hizkuntzako $P$ perpausa egiazkoa da bba $B_{1}, \ldots, B_{n}$ baldintzak betetzen badira munduan.

b. $H$ hizkuntzako hiztun batek $P$ perpausa egiazkotzat jotzen du bsb $B_{1}, \ldots, B_{n}$ baldintzak betetzen badira munduaren bere interpretazioan (oroimen- eta prozesatze-mugen arabera, eta hiztunen arteko uniformetasun-idealizazio baten pean).

Hau da, egia ez da jada perpaus baten eta munduaren arteko erlazio gisa ikusten, baizik eta perpaus baten eta hiztunak munduaz egiten duen interpretazioaren arteko erlazio gisa. Pareko berrinterpretazioak egin behar dira inplikazio, aurresuposizio eta abarren gisako erlazio logikoetarako.

Zama erabakigarria ezartzen dio berrinterpretazio horrek I-semantikaren teoriari. Jada «mundua» ezin da logikaren edo multzo-teoriaren arabera soilik ezaugarritu, semantika formalak egin ohi duen bezala. Baizik eta arazo enpirikoa da zehaztea zer motatako entitateak dauden munduan gizakiek hura interpretatzen duten eran. Entitate horiek ezaugarri daitezke edo ez logika estandarraren edo multzo-teoriaren arabera; eta, egia esan, erakusten dute ezin direla ezaugarritu, behean ikusiko dugun bezala. Gainera, munduaren giza interpretazioaren hiztegian baieztu behar dira egibaldintzak.

Hurbiltze horren baieztapena da jendeak, linguistikoki komunikatzen denean, ez duela munduari buruz komunikatzen besterik gabe, baizik eta munduari buruz gizakiaren eran ulertuta. Hiztunek erreferentzia egiten dieten entitateak ez dira «munduan» dauden entitateak besterik gabe, baizik eta munduaren giza interpretazioan erabilgarri dauden entitateak. Horien artean dira objektu eta gertaera fisikoak, inguru birtualen gisako alegiazko objektuak, Aita Noel gisako fikziozko objektuak, ezkontzen eta unibertsitateko 
ikasketen gisako gizarte-eratzeak, asmo eta usteen gisako gogo-eratzeak, eta zenbakien eta operatzaile logikoen gisako eratze teorikoak. I-semantikaren ikuspegitik, estatus sendo bera dute horiek guztiek. (Jackendoffek (1983) eta Lakoffek (1987) lantzen dute jarrera hori zehatz-mehatz).

Beste galdera enpiriko bat da nolako harremana duten mota desberdineko entitate horiek mundu erreal «errealarekin», edo, bestela, «buruko esanahiak» nola bihurtzen diren «esanahidun». Kapituluaren bukaeran itzuliko gara gai horietara, oraindik ere eztabaidagarri diren horietara.

\section{Hiztegi semantikoaren konposizionalitatea eta unibertsaltasuna}

Ohiko semantika formalak bezala, sintagma eta perpausen esanahiak osagai diren item lexikoen esanahietatik osatzera emanak daude I-semantikako hurbiltze guztiak. AAn oinarritutako hurbiltze batzuek salbu, guztiek jakintzat jotzen dute egitura sintaktikoak gidari garrantzitsu gisa jokatzen duela osagaietatik sintagmen esanahiak eratzean.

Hala ere, semantika formaleko lan gehienak baino harago doaz I-semantikako ia hurbiltze guztiak, item lexikoak unitate txikiagoetan semantikoki deskonposatzeko konpromiso serioa hartzen baitute. ${ }^{3}$ Jardun horrek garrantzi handiko fruitua eman du inferentzia-ereduak eta jokaera sintaktikoaren ereduak azaltzeko (behean ikusiko ditugu horietako batzuk); hori bakarrik bada nahikoa justifikazio ahaleginerako.

Baina, gainera, deskonposizio lexikalaren oinarriei buruzko galderetara garamatzate I-semantikaren suposizioek. I-hizkuntzalaritzako oinarrizko arazoaren antzera - nola bereganatzen duen haurrak hizkuntza bateko gramatika-, I-semantikak honako galdera honi egin behar dio aurre: nola bereganatzen du haurrak hiztegia, bereziki hitzen esanahia? Nondik datoz soinuei eta egitura sintaktikoei lotzen zaizkien kontzeptuak?

Gogoa sistema formalen bidez ezaugarri daitekeela dioen ikuspegia kontuan hartuta, ikastea hartu behar da badiren unitate formalak egitura handiagoetan konbinatze gisa. Gainera, nonbait hasi behar dute «badiren unitate formalek»: primitiboen hiztegi batek eta konbinazio-printzipio batzuek (adib., axiomek) egon behar dute sistema oinarritik hasteko. Sistema horrek, beharrezkotasun logikoz, sortzetik egon behar du gauzatuta garunean, definizioz ezin baita ikasi. (Argumentu hori Fodorri (1975) zor zaio).

\footnotetext{
3 Fodorren (1975) pentsamenduaren hizkuntzaren hipotesia da salbuespen garrantzitsu bakarra. Hemen azaltzeko konplexuegiak diren arrazoiengatik, Fodorrek baieztatzen du item lexiko morfemabakarren esanahiak sortzetiko monada deskonposaezinak direla. Ikus Jackendoff (1983 7.5 atala; 1992, 2.8 atala, 8. kapitulua) eztabaidarako.
} 
Izan ere, ikastearen teoria guztiek aurresuposatzen dituzte sortzetiko oinarri batzuk. Baliteke asoziazio-printzipioak bezain sinplea den zerbait izatea, edo Fodorren (1975) errepertorioa bezain aberatsa den zerbait, hitz morfemabakar guztien esanahiak bere baitan hartzeko nahikoa dena. Galdera enpiriko interesgarria, hortaz, ez da hitzen esanahien atzean ba ote den sortzetiko oinarririk, baizik eta preseski zein den sortzetiko oinarri hori. Praktikan, I-semantikari buruzko hurbiltze gehienek konbinazio-oinarri nahiko aberatsa onartzen dute hitzen esanahientzat, primitibo kontzeptual substantiboz osatutako errepertorio handi samarra duena.

Batzuetan, objekzioa egiten zaio horri (adib., Partee 1993b), primitibo semantikoak sortzetikoak izateak benetan dagoen baino unibertsaltasunmaila handiagoa ekarri beharko lukeela munduko hizkuntzen semantika lexikoan. Bi erantzun daude objekzio horrentzat. Lehenengoak gramatika sortzailearen ereduari jarraitzen dio. Gramatika Unibertsala fonologian eta sintaxian sortzetikoa izateak ez dakar sekulako uniformetasuna hizkuntzaren alderdi horietan: aukeren errepertorio batetik hartu eta hauta dezakete hizkuntzek; batzuk, gainera, kontraesanean daude bata bestearekin (hots, kasu-markatze akusatiboa vs ergatiboa). Gauza bera gerta daiteke erraz semantikarekin: sortzetiko oinarrian erabilgarri dauden kontzeptuetatik aukera desberdinak gramatikalizatzeko edo lexikalizatzeko hautua egingo dute hizkuntzek; hala, baliteke semantikoki konparaezinak diren itxura ematea hizkuntza desberdinek.

Bigarrenik, ez da nahitaez egia primitibo semantiko/kontzeptual oro (edo baten bat) independenteki adierazgarria dela hitz gisa. Hizketa-soinu isolagarri txikienak (fonemak) bere kabuz ager ezin daitezkeen ezaugarri berezien konposatuak diren bezala, badirudi hitzen esanahiak oro konposatuak direla, isolatuta ager ezin daitezkeen osagai semantiko/kontzeptualez osatuak. Hau da, hitzen esanahiak entitate «molekularrak» dira «kontzeptuen kimikan»; primitibo semantiko/kontzeptualak, berriz, subatomikoak edo quarken antzekoak dira. Hori horrela, item lexiko baten azken deskonposizioa ezin da hizkuntz parafrasi baten bidez adierazi.

Parafrasi-definizioak ezin egin izatea deskonposizio lexikalaren kontrako argudiotzat hartzen da askotan (adib., Fodor, Garrett, Walker eta Parkes 1980), baina, benetan, parafrasi-definizioak espero daitezke bakarrik primitibo semantiko oro bakoitza hitz batekin adieraz badaiteke, eta konposizio semantikoaren printzipio oro konposizio sintaktikoaren printzipioen pareko egin badaiteke. Bestela (benetan gertatzen den bezala), erabat naturala da parafrasi-definizioak ez egotea.

Orduan, nola justifikatzen du batek proposatutako primitibo semantiko/ kontzeptuala? Hasteko, kontuan hartu ezin dela isolatuta justifikatu; hura kokatuta dagoen gainerako sistema axiomatikoaren testuinguruan soilik du zentzua. Sistema axiomatikoarentzako proposamen partikularra, berriz, ez 
da logikoki bakarrik justifikatzen, baita enpirikoki ere; honen arabera: zein egoki azaltzen duen hizkuntzaren eta kognizioaren fenomeno semantikoa. Batzuetan, honela hazten da arazoa: nola esan dezakeen inoiz batek «benetan» primitiboa ote den proposatutako primitibo multzoa. Nahikoa da esatea badirudiela galdera horrek ez dituela sekula gogogabetu fisikariak, zeinek hain zuzen akuilu gisa hartzen duten, deskonposizio sakonagoak azalpen sakonagora eramaten ote duen ikusteko. Praktikan, horixe gertatzen da semantika lexikoan ere.

\section{Giza kontzeptuek hizkuntza naturalaren semantikarekin duten erlazioa}

I-semantikaren teoriaren barnean biak bat eta bera izango balira bezala erabili du «semantiko/kontzeptual» esapidea azkeneko atalak. Izan ere, I-semantika egiten duten gehienek emantzat jotzen dute hizkuntza naturalaren esanahiak eta giza kontzeptuak identifikatzea; baina bi jarrerak eztabaida merezi dute.

I-semantikako oinarrizko hipotesia da hizkuntza naturaleko egitura sintaktikoek eurek adierazten dituzten kontzeptuekin erlazionatuta egon behar dutela itzulpen- edo korrespondentzia-arauen multzo baten bidez; «kontzeptuen» baitan dago giza ezagutzaren aberastasun eta elkarrekiko lotura guztia (batzuetan, ezagutza «entziklopedikoa» esaten zaio giza ezagutzari eta, beste batzuetan, «pragmatika»). Hala ere, galdera sortzen da erlazioa zuzena den (20.2a irudia) edo baden identifika daitekeen maila independente bat sintaxiaren eta kontzeptuen artean, «semantika zentzu hertsian» esan dakiokeena (20.2b irudia).

\section{2 irudia}

a. egitura sintaktikoak egitura semantiko/kontzeptualak

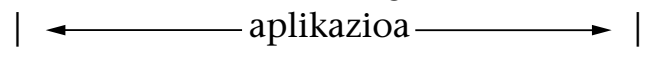

b. egitura sintaktikoak egitura semantikoak kontzeptu-egiturak

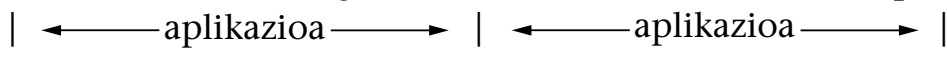

20.2b irudiaren gisako bi pausoko aplikazioaren aldekoentzat, arazoa da zer eginkizun duen egitura semantikoaren maila independenteak. Katzen hasierako lanetan (1972an, esaterako), egitura semantikoa ulertzen da perpausen arteko erlazio semantikoak (hala nola, inplikazio logikoa, sinonimia, anbiguotasuna eta anomalia) soilik biltzen dituen baina orokorrean «munduari buruzko ezagutza» adierazten ez duen errepresentazio-maila gisa. Semantikari formal berriagoek ere onartzen dute, batzuetan, halako semantikaren maila. Izan ere, frogatu da ezinezkoa dela erlazio «semantiko» hutsak munduari bu- 
ruzko ezagutzatik eta interpretazio metaforikoetatik bereiztea, orokortzeak ikaragarri galdu gabe (Jackendoff 1981, 1983; Lakoff eta Johnson 1980; Lakoff 1987); beraz, ezin zaio eutsi Katzen egitura semantikoaren ikuspegiari.

Egitura semantikoaren bigarren ikuspegi bat era independentean etorri da; esate baterako, Pinkerren (1989) eta Bierwischen $(1982,1992)$ lanetan, non errepresentazio-mailak kodetzen dituen, hain justu, egitura sintaktikoan eragina duten esanahiaren alderdi horiek. Esaterako, hizkuntza askok bereizketa sintaktikoak egiten dituzte numeroan, generoan eta bizidun/bizigabe izatean oinarrituta, baina batek ere ez du egiten bereizketarik kolorean edo txakurren eta katuen arteko aldean oinarrituta. Ideia, hortaz, da egitura semantikoak numeroa, generoa eta bizidun/bizigabe izatea kodetzen dituela, baina kolorea edo espezieak ez. Era berean, hizkuntzek bereizketa sintaktikoak egiten dituzte ekintza- eta egoera-aditzen artean, baina ez korrika egiteari dagozkion aditzen eta oinez ibiltzeari dagozkion aditzen artean. Hor ere lehenengo bereizketa bakarrik azalduko litzateke egitura semantikoan. Batzuetan, inplikazioa da kontzeptu-egitura unibertsala dela; egitura semantikoa, berriz, aldatu egiten dela hizkuntzatik hizkuntzara, zein bereizketa kontzeptual gramatikalizatzen diren. (Ikus, adib., Talmy 1980, Choi eta Bowerman 1991, hizkuntzen arteko desberdintasunen eztabaidarako).

Dena dela, gertaeren konfigurazio hori 20.2a irudian bezala egituratutako teoria baten baitan erreproduzi daiteke, hizkuntza bakoitzari dagozkion alderdi semantikoak zuzenean sintaxiaren eta kontzeptu-egituraren arteko aplikazioan jarriz. Ideia da bereizketa kontzeptualen sail mugatu batek bakarrik izan dezakeela eragina aplikazio horretan; hala, gainerakoak opakuak dira ezinbestean sintaxiarentzat. Hizkuntzen arteko aldakortasuna, horri dagokionez, aplikazioan eragina duten faktore kontzeptualen aldakortasunari egozten zaio. Ondorioz, ez da beharrezkoa erabat linguistikoa den semantikaren aparteko mailarik.

Ohartu nola den hori sintaxia-fonologia interfasearen jokabidearen antzekoa. Bereizketa fonologiko asko dago sintaxian eginkizunik ez duena, baina horrek ez garamatza sintaxiarentzat adierazgarri diren bereizketa fonologikoak soilik biltzen dituen beste errepresentazio-maila bat proposatzera postulatu gisa. Baizik eta ideia da fonologiaren eta sintaxiaren arteko aplikazioak ezin duela izan segmentu-edukiaren (esaterako, txakur eta katu fonema-sekuentzien arteko aldearen) eraginik, silaba kopuruen (kameilua vs dromedarioa) eraginik, eta abar. Aitzitik, aplikazioak badu hitzen eta sintagmen mugen eragina, hizkien egiturena, eta abarrena. Hau da, errepresentazio-mailen arteko aplikazioa homologia partziala da soilik, ez egituraren elementu guztien arteko bana-banako korrespondentzia.

Ez dago garbi egitura semantikoaren ikuspegi horietako zein nagusituko den azkenean. Kapitulu honen gainerakoak azkeneko ikuspegia egingo $\mathrm{du}$ bere eztabaida gehiagorik gabe, errepresentazio semantikoak giza egitura 
kontzeptualekin (beharbada horien azpimultzo batekin) identifikatzea onartuz, arloko lanik gehienen arabera.

\section{Kontzeptu-kategorien izaera ez-kategorikoa}

I-semantikan esanahi lexikalari emandako garrantziak kategorizazioaren fenomenoaren azterketa gogoangarria sorrarazi du: gizakiek nola jartzen dituzten banakoak kategoriatan, eta kategoria-sistemak nola dauden eraikita gogoan. Auzi semantikoa izaki, arazoa formula daiteke Hau X bat da perpausarentzat egibaldintzak mugatzearen zeregin gisa, non $X$ den delako kategoria. Semantika formalaren tradizio nagusiak ez bezala, zeinak kritika gutxi samarrekin onartzen duen egibaldintza beharrezko eta nahikoen tarskiar irizpidea, I-semantikako ikerketa gehienak (batik bat Jackendoff 1983k eta Lakoff 1987k) azpimarratzen du tarskiar baldintzek ez dutela giza kategorien aberastasuna ezaugarritzeko gaitasunik. Sortu diren arazo batzuen adibideak aurkezten ditu atal honek.

\subsection{Mailakatutako mugak dituzten kategoriak}

Hartu gorri kategoria. Ezin da identifikatu hautemandako tonu jakin batekin, tonu multzo zabalari esaten baitzaio gorri. Haatik, tonuak aldatu egiten direnez ezin hautematezko eran gorritik laranjarantz, bada puntu bat behatzaileek ez dauzkatena garbi beren judizioak. Baliteke zalantza eta behatzaileen arteko desadostasuna izatea. Gainera, zein tonu aurkeztu diren aurre-aurretik, baliteke tonu jakin bati buruzko judizioa aldatzea (erdiguneko gorriaren ondoren ematen bada, laranjatzat hartzen da, baina, erdiguneko laranjaren ondoren aurkezten bada, gorritzat hartzen da). Hau da, erdiguneko multzo bat dago non judizioak ziurrak eta egonkorrak diren, baina mugako multzo bati itzal egiten dio horrek, non gatazka dagoen ondoko kategoria batekin, eta judizioak ez hain ziurrak eta testuinguruaren mendekoago bihurtzen diren.

Kategoria baten mugako «lausotasun» hori ez da hiztunek «gorriren esanahia ez jakitea»ren arazoa, baizik eta bere-berea du kontzeptuaren beraren egiturak. Batek gorri «tarskiarrago» egin dezake laranja, arrosa, more eta marroiarekin muga zorrotzak finkatuz, baina horrela bat ez da ari hitzaren esanahi arruntarekin. Orobat, batek gorri-laranja kategoria berria sor dezake mugan; baina mota bereko lausotasuna gertatzen da, orduan, gorriaren eta gorri-laranjaren mugan. (Putnam 1975ek nabarmentzen du badela halako fenomenoa; koloreei buruzko judizioen lan klasikoa da Berlin eta Kay 1969).

Antzeko muga-arazoak sortzen dira bero eta altu gisako hitzekin; arau batetik desbideratze esanguratsua adierazten dute. Zein da hozberoaren mu- 
garik apalena, esaterako, zopa beroarentzat, edo altueraren mugarik txikiena emakume altuarentzat? Kontzeptu horien egiturak bere-berea du mugak tradizionalki zorrotzak ez izatea; ezin da esan emakume bat emakume altuen multzoan edo hortik kanpo dagoela erabat.

Bide batez, adjektibo horiek erakusten dute, halaber, elkarren menpe daudela esanahi linguistikoa eta ezagutza entziklopedikoa, egiaren judizioetan. Zeren, askotan esan den bezala, elefante txiki bat sagu handi bat baino handiagoa baita: batek direlako animalien neurri arruntari buruz duen ezagutzaren araberakoa da araua, eta horri aplikatzen zaio adjektiboa. (Bierwisch eta Lang 1989 kasu bat arau batekin erlazionatzen duten adjektiboez mintzatzen dira zehatz-mehatz). Era berean (Talmy 1978k azpimarratu bezala), izarren arteko hurbiltasuntzat hartzen dena altzarien piezen arteko hurbiltasunaren guztiz bestelakoa da metrikoki; mintzagai dugun kategoriako indibidualen artean espero daitekeen distantzia arruntaren arabera dago definituta hurbiltasuna ere. (Ikus Pustejovsky 1991 hobeto landutako era honetako adibideetarako, Millikan 1984k objektuen berezko funtzio esaten dienekin du zerikusia; Katzen 1966ko onen tratamendua adibide goiztiarra, nolabait trakets moldatutakoa da).

\section{2. «Sorta»-kontzeptuak}

Wittgensteinen (1953) jokoren analisia da fenomeno horren adibide klasikoa, non frogatzen duen ezinezkoa dela jokoak beste ekintza batzuetatik bereizten dituen beharrezko baldintza bat aurkitzea. Iradokitzen du «familiaantzekotasunaren» arabera ulertzen dela hitza: jokoak definitzen dituen baldintza multzo bat dago; baina ez dago horiek guztiak betetzen dituen jokorik, eta horietako bat ere ez dute elkarrekin joko guztiek. Hau da, baldintza bat bera ere ez da beharrezkoa, baina horien hainbat konbinazio egoki aski dira banako bat kategoriako kide gisa hartzeko. Kategoria horiei sorta-kontzeptuak esaten zaie orain.

Roschek (1973, 1975, 1978; Rosch eta Mervis 1975) garatu du azterketa hori; esperimentuen bidez erakusten du balitekeela kategorizazio-judizioek «tipikotasunezko» mailaz mailako aldaketa bat izatea, kategoriaren ale tipikoetatik (adib., txantxangorria hegazti «tipikoa» da) ale atipikoetaraino (adib., pinguinoa hegazti «atipikoa» da) hedatzen dena. Sorta-kontzeptua sortzen duen baldintza multzoa da tipikotasun-efektuen ${ }^{4}$ iturrietako bat: bal-

\footnotetext{
4 Tipikotasun-judizioak kolore-kontzeptuetan izaten dira, esaterako, non gorri laranjaska baino tipikoagotzat jotzen den erdiguneko gorria. Armstrong, Gleitman eta Gleitmanek (1983) erakusten dute sorta-kontzeptu ez direnentzat ere har daitezkeela tipikotasun-judizioak; esaterako, 38 zenbaki bikoitia ez da 4 bezain tipikotzat hartzen eta moja ez da etxekoandrea bezain emakume tipikotzat hartzen. Beraz, kategorizazioari buruzko hainbat fenomenoren zantzua
} 
dintza gutxiago betetzen dituzten adibideak ez dira hartzen, oro har, baldintza gehien betetzen dituzten adibideak bezain tipikotzat.

Ikus daitezke sorta-baldintzen eraginak bi baldintza soilik dituzten kontzeptuetan. Climb ${ }^{5}$ (igo) aditza da kasu bat; Fillmorek (1982) hitz egin zuen lehenengo aldiz horretaz. Hartu honako adibide hauek:

(9) a. Bill climbed (up) the mountain. [Billek mendian gora egin zuen; Billek mendia igo zuen.]

b. Bill climbed down the mountain. [Billek mendian behera egin zuen; Billek mendia jaitsi zuen.]

c. The snake climbed (up) the tree. [Sugeak zuhaitzean gora egin zuen; Sugea zuhaitzera igo zen.]

d. ?*The snake climbed down the tree. [Sugeak zuhaitzean behera egin zuen; Sugea zuhaitzetik jaitsi zen.]

Bi baldintza kontzeptual independente ditu climbingek [igotzeak]: (1) banako bat goraka doa, eta (2) banakoa ahalegin beteko mugimendu zuhurrekin ari da mugitzen. (9a)ren oso litekeena den interpretazioan, bi baldintzek egiten dute topo. (9b)k lehenengo baldintza urratzen du; eta, sugeek ezin dutenez eskalatu, (9c)k bigarrena urratzen du. Hala ere, climbingen kasu onargarriak dira bi adibideak. Haatik, bi baldintzak urratzen badira, (9d)n bezala, ezin da climbing gisa deskribatu ekintza. Beraz, bi baldintzetako bat ere ez da beharrezkoa, baina bietako edozein da nahikoa. Gainera, climbing estereotipikoagotzat jotzen da (9a)ren lehenetsitako interpretazioa, non bi baldintzak betetzen diren; (9b) eta (9c) nolabait bazterrekoagotzat, baina oraindik ere bete-betean zilegi diren kasutzat juzgatzen dira.

Pareko azterketa proposatu dute lie [gezurra esan] (Coleman eta Kay 1981) eta see [ikusi] (Jackendoff 1983, Miller eta Johnson-Laird 1976n oinarritua, neurri batean) aditzentzat. Antzeko fenomenoa sortzen da izenentzako sarrera lexikoetan ere. Esaterako, chair [aulki] estereotipiko batek forma estereotipikoa eta funtzio estandarra ditu. Kategoriaren kasu bazterrekoagoak dira funtzio egokia baina forma okerra duten objektuak - adibidez, puf eserlekuak-; eta halaxe dira forma egokia duten baina funtzioa bete ezin duten objektuak —adibidez, egunkariz egindako aulkiak edo aulki izugarriak-. Bi baldintzak urratzen dituen objektua —esaterako, zimurtutako egunkarien

baino ez da berez tipikotasuna. Baina mailakatutako judizioetarako iturburu asko izateak ez du ahultzen sorta-kontzeptuak izatea, Armstrong eta bestek esaten dutenaren kontra. Ikus Jackendoff 1983, 7. kapitulua, 6. oharra eta Lakoff 1987, 9. kapitulua eztabaidarako.

5 Adibide hau eta gainerakoa bere horretan utzi ditut (esan nahi baita, jatorrizko hizkuntzan, ingelesez; guztiekin berdin jokatze aldera), eta euskarazko itzulpena kako zuzenen artean eman dut. Izan ere, horietako zenbait euskaratuz gero, galdu egingo litzateke azalpenean esaten dena. [Itzultzailearen oharra]. 
pila - ez da inola ere aulki bat, irudimena erabat behartuta ere. Lakoffek (1987, 4. kapitulua) mother [ama] kontzeptuarentzat erabili zuen halako analisia; kontzeptu horrek bere baitan hartzen ditu material genetikoa ematen duen emakumea, haurra ekartzen duen emakumea eta haurra hazten duen emakumea. Gaur egungo adopzioaren eta ingeniaritza genetikoaren antolamenduetan, ez dute beti bat egiten hiru horiek; eta, ondorioz, ez da beti estereotipikoki erabiltzen terminoa.

Jackendoffek (1983) lehentasun-arauen sistema esaten dio era horretako baldintzen sistemari; Lakoffek (1987) idealizatutako eredu kognitiboa(ren alderdi bat) esaten dio; antzeko eraginak dituzte Minskyren (1975) markoek. Halako kontzeptuak, tarskiar kontzeptuen gisan, baldintzen konbinazioak dira. Tarskiar kontzeptuetatik desberdintzen dira baldintzak desberdin konbinatzean. Konbinazioa ez da konjuntzio logiko bat, objektu bat kategorizatzeko nahikoa baita baldintzen multzo osoa baino gutxiago asetzea. Baina ez da disjuntzio logiko bat ere, disjuntzio logikoak ez baititu egoki bereizten erdiko eta mugako adibideak. Hau da, hitzen esanahien teoria egokiak eredu logiko estandarrek baino aberatsagoa izan beharra dauka. (Baldintza horien eragina atzematetik gertuago dago default logika; default balio gisa jokatzen dute baldintza horiek, non ez dagoen kontrakoarentzat frogarik; esaterako, (9a)n).

I-semantikaren helburu psikologikoak kontuan hartuta, teoria aberaste horrek erakusten du onargarria dela eremu psikologiko zabalagoetan. Baldintzek sorta-kontzeptuetan erlazionatzeko duten era funtsezkoa da ikuste-pertzepzioan (Wertheimer 1923, Marr 1982), pertzepzio fonetikoan (Liberman eta Studdert-Kennedy 1977), musika-pertzepzioan (Lerdahl eta Jackendoff 1983) eta gricear inplikaturan (Bach eta Harnish 1979). Gainera, interakzio hori garunean irudikatuta egongo da ziur asko, non neurona bat piztea ez den normalean beste pizte neural batzuen funtzio zurruna (konjuntzio logikoa nola), baizik eta askotariko indarren sinapsi kitzikatzaile eta inhibitzaile askoren konposatua. Hala, sorta-kontzeptuak, nahiz eta ezohikoak izan molde logikoetan, nahiko naturalak dira molde psikologikoetan.

\subsection{Esanahien irudi-antzeko osagaiak}

Putmanek (1975) iradokitzen du, kategoria askorentzat, kasu estereotipikoen irudiak dituztela hiztunek euren buruetan (nahiz eta berak, E-semantikara emana izaki, ez dituen irudi horiek esanahien partetzat hartzen). I-semantikan, hedatuta dago irudi-antzeko errepresentazioak kontzeptuen partetzat baliatzea, proposamen zehatz gutxi dagoen arren. Jackendoffek (1987) eta Landau eta Jackendoffek (1993) iradokitzen dute espazioaren arabera ulertzen diren entitateak (adib., objektu eta ekintza fisikoak) espazioerrepresentazio baten arabera kodetuta daudela, neurri batean, zeina Marren 
(1982) 3D eredu-egituraren aberastutako bertsioa den. Oso onartuta dago modalitate jakinari dagozkion irudien arabera kodetuta daudela, neurri batean, beste fenomeno sentsorial batzuk ere; esaterako, soinuak, usainak, zaporeak eta gorputzeko sentipenak.

Berriro ere, nahiz eta balitekeen zuhurtasunak halako beste errepresentazio motak esanahietan sartzearen kontra egitea, gogoeta psikologikoek babestu egiten dute erabat. Objektu fisiko bat identifikatzeko prozesuaren zati bat da haren itxura adibide ezagunekin edo adibide ezagunak laburbiltzen dituen eskema batekin alderatzea. Kontuan hartuta ikuste-sistemak era independentean kodetu behar dituela halako eskemak — baita organismo ez-linguistikoetan ere-, ez dago arrazoirik sistema kontzeptualak informazio hori ezin erabili ahal izateko. Ez balu erabiliko, sistema kontzeptualean kodetu beharko litzateke, nolanahi ere, itxurari buruzko informazioa, kategorizazioa gertatzeko; ondorioz, beharrik gabe bikoiztuko litzateke informazioa.

Badago beste arrazoi bat ere irudietan kodetzea hitzaren esanahiaren partetzat onartzeko. Formaren ezaugarri zehatz asko (baita soinuak, usainak, zaporeak eta gorputzeko sentipenak ere) ez dira egokiak inolako ezaugarri-deskonposizio aljebraikorako (edo proposizionalerako). Esaterako, ahate baten itxuraren eta antzara batenaren arteko desberdintasuna [ \pm lepo luzea] gisako ad hoc ezaugarrien arabera soilik adieraz daiteke aljebraikoki. Hala ere, desberdintasun hori erabat naturala da Marren 3D eredu-egituraren moduko sistema batean, zeina egokituta dagoen formaren eta inguruaren desberdintasun antzemanezinak hautemateko.

Horrek ez du esan nahi kategorizazio guztiak irudizko errepresentazioetara ekar daitezkeenik. Esaterako, irudizko errepresentazioak ezin kode dezake tipoen eta aleen arteko desberdintasuna edo ahateen lekua uretako hegazti, hegazti eta animalien taxonomian. Ezin kodetu ditzake esanahiaren alderdi kuantifikazionalak ere. Aitzitik, egokia dirudi errepresentazio aljebraikoak eta irudizkoak kategorien giza ezagutza kodetzeko lanaren pisua - nahi baduzu, Putmanen «lan linguistikoa banatzea», gogoaren moduluei aplikatuta- euren artean banatzen duten gisa hartzeak.

Beraz, kodetze sentsorial/irudizkoen eta kodetze proposizional/aljebraikoen artean ezarritako loturak laguntzen du, baita ere, azaltzen nola litekeen ikusten dugunari buruz hitz egitea. Jendeak hizkuntzak erreferentzia egiten dion entitate bat ikusiz identifika dezan, ezin dira zuzenean munduarekin alderatu hizkuntzatik eratorritako egitura semantiko/kontzeptualak. Aitzitik, korrespondentzian jarri behar dira ikuste-modalitatetik sortutako errepresentazioekin, ikuste-inputarekin alderatu ahal izateko. Kausazko mekanismo onargarri horrexekin bakarrik izan dezake eragina ikuste-inputak hizkuntza-adierazpenean. Hortaz, I-semantikaren printzipio psikologikoak behin eta berriz aipatzeak ondorio garrantzitsuak ditu erreferentziaren teoriarentzat. 10. atalean itzuliko gara gai horretara. 


\section{Espazio-adierazpenak}

Semantika formala ez bezala, I-semantikako ikerketa arduratuta egon da beti espazio-kokapenari eta -mugimenduari buruzko adierazpenen interpretazioarekin. Hainbat arrazoi natural dago enfasi horretarako, I-semantikaren oinarrizko helburuetatik sortutakoak guztiak. Lehenik, aberatsa da oso espazio-kokapenaren eta -mugimenduaren arloa. Bigarrenik, espazio-mugimenduari eta -kokapenari buruzko perpausak egiaztagarriak direnez hautemanez (ikus aurreko azpiatala), egiari, inferentziari eta anbiguitateari buruzko judizioak nahiko zorrotzak eta aski egituratuak dira. Hirugarrenik, 9. atalean ikusiko dugun bezala, kontzeptuen beste arlo asko antzera daude egituratuta aljebraikoki; beraz, baliteke espazio-adierazpenak ulertzeak onurak ekartzea hizkuntza era orokorragoan ulertzeko.

Laugarrenik, berriro semantikaren ezaugarri biologikora joz, espero izatekoa da espazio-kokapenaren eta -mugimenduaren kodetze psikologikoa hizkuntza baino askoz lehenago garatuko zela, gure aurreko ugaztun guztiek erakusten baitute munduan zehar ibiltzeko gaitasuna. Bosgarrenik, Piagetek (1970) azpimarratzen duen bezala, haurrek hitz egiten hasi baino askoz lehenago erakusten dute espazio-kontzeptuak ulertzen dituztela beren jarrera sentsoriomotorrean. Espazio-kontzeptuak aztertzean, hortaz, biologikoki eta bilakaeran hizkuntz ezagutzaren aurrekoa den giza ezagutza mota batean sartzen ari da bat; interes berezia ematen dio horrek. (Miller eta Johnson-Lairdek (1976) azpimarratzen dituzte arrazoi horietako asko, baita geroagoko idazleek ere).

Eremu horretako oinarrizko fenomeno bakarra gainetik ukitzeko lekua soilik dago hemen: irudi-hondo antolatzea. Hala ere, funtsezkoa da fenomenoa, Gruber (1965), Talmy (1978, 1983), Langacker (1987) eta Jackendoffen (1983) teorien oinarria baita, eta esanahi preposizionaletako lan askoz zehatzagoen azpian datza; hala nola, hauetan: Brugman (1981), Herskovits (1986), Vandeloise (1986) eta Landau eta Jackendoff (1993).

Hartu The cat sat on the mat [Katua alfonbraren gainean zegoen] gisako perpaus arrunt bat. Deskribatzen diren bi objektuak, katua eta alfonbra, asimetrikoki adierazita daude: the cat [katua] perpausaren subjektua da, zuhaitz sintaktikoaren goialdetik gertu; the mat [alfonbra], berriz, behean txertatuta dago, preposizio-sintagmaren barruan. Hasiera batean, (10) gisa kode daiteke kontzeptualki katuaren eta alfonbraren arteko espazio-erlazioa; on [gainean] bi objektuen arteko bi argumentuko erlazioa da. Gisa horretako proposamenak ez dira ezohikoak.

(10) sit (the cat) and on (the cat, the mat) [egon (katua) eta gainean (katua, alfonbra)] 
Hala eta guztiz ere, goian aipatutako ikerketak baieztatzen du perpausaren esanahia asimetrikoa dela, sintaxia den modu berean zehazki:

1. Alfonbra erreferentzia-objektu edo mugarri gisa kontzeptualizatzen da.

2. Erreferentzia-objektuak espazioko eremu bat zehazten laguntzen du. On the mat PSren bidez dago adierazita espazioko eremu hori: alfonbraren gainazala ukitzen duen eremua da. Preposizio desberdinek erreferentzia-objektu berean oinarritutako eremu desberdinak zehazten dituzte; esaterako, under the mat [alfonbraren azpian], beyond the mat [alfonbratik harago] eta off the mat [alfonbratik kanpo].

3. Aditzak objektu figuratibo bat, alegia katua, kokatzeko erabiltzen du espazioko eremu hori. Adibide honetan, sat aditzak adierazten du, halaber, objektu figuratiboaren jarrera eta delako egoeraren iraganaldia.

Beraz, The cat sat on the mat horren azterketa informala (11)ren antzeko zerbait da.

the cat objektu figuratiboa sat

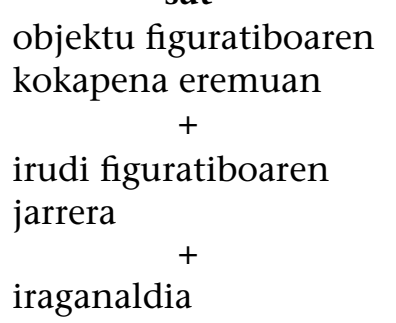

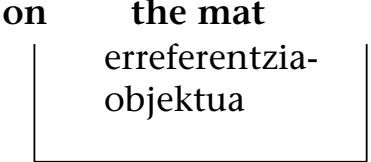

eremua erreferentziabjektua

Asimetria argiago ikusteko, alderantziz jar ditzakegu rolak, eta The mat lay under the cat [Alfonbra katuaren azpian dago] perpausa sortuko da. Arraroa dirudi nabarmen perpaus horrek, nahiz eta deskribatzen duen egoera fisikoa berbera izan; eta gramatika akatsik gabea da dudarik gabe. Ikusteko horrek zergatik izan behar duen horrela, hartu objektu figuratiboen eta erreferentzia-objektuen rolak modu gogobetegarrian truka daitezkeen egoera bat; esaterako, (12).

(12) a. The star is inside the circle. [Izarra biribilaren barruan dago.]

b. The circle lies around the star. [Biribila izarraren inguruan dago.]

Hemen ere asimetria dago bi perpaus horien bidez adierazitako kontzeptuetan, perpaus horiek galderen erantzun gisa erabiliz ikus daitekeen bezala. (Gruber 1965i zor zaio argumentu hori). 
(13) a. Where is the star? [Non dago izarra?]

b. Where is the circle? [Non dago biribila?]
RAY JACKENDOFF

It is inside the circle.

[Biribilaren barruan dago.]

??The circle lies around it

[??Biribila haren inguruan dago.]

It lies around the star.

[Izarraren inguruan dago.]

??The star is inside it

[??Izarra haren barruan dago.]

Hau da, (12a) perpausa askoz era egokiagoa da biribila non dagoen esateko, eta (12b) perpausa askoz era egokiagoa da izarra non dagoen esateko. Desberdintasun hori (11)ko azterketaren bidez dago azalduta, zeinak dioen erreferentzia-objektua (preposizioaren objektua) objektu figuratiboa (perpausaren subjektua) kokatzen laguntzeko dela, ez alderantziz. Hori horrela, garbi dago zergatik dirudien arraroa The mat lay under the cat [Alfonbra katuaren azpian dago] perpausak: esaten ari da nola aurkitu alfonbra katua erreferentzia-puntu gisa erabilita, baina zaila da batek hori egin nahiko lukeen egoerak irudikatzea.

Oraindik harrigarriagoa da Talmyk (1983) aipatzen duen kasu bat; next tok [ondoan] erabat simetrikoa dirudi: $X$ Yren ondoan badago, begien bistakoa da $Y$ Xren ondoan dagoela. Haatik, The bike is next to the house [Bizikleta etxearen ondoan dago] ongi dago, baina The house is next to the bike [Etxea bizikletaren ondoan dago] arraroa da garbi. Arrazoia da objektu mugiezin handi samarrak erreferentzia-puntu gisa erabiltzen direla normalean objektu mugikor txikiak kokatzeko, baina ez alderantziz. (Ohartu delako etxea jostailuzko «Monopoly» etxea bada, hortaz txiki eta mugikor samarra $d a$, askoz onargarriagoa dela The house is next to the bike [Etxea bizikletaren ondoan dago]).

Perpaus horietako asimetriek ez dute zerikusirik ingelesaren sintaxiarekin, zeinak dioen soilik IS subjektua lehenengo doala, preposizioaren objektua preposizioaren atzetik doala, eta abar. Eta, (12)-(13)k argi uzten duten bezala, asimetriek ez dute zerikusirik mundu fisikoarekin ere per se. Aitzitik, giza gogoak hautemandako mundua kontzeptualki antolatzeko duen erarekin dute zerikusia: nola erabiltzen ditugun objektuak beste objektu batzuk aurkitzeko.

Munduko hizkuntza guztietan errepikatzen da antolaketa kontzeptual hori, eta horrekin doan gramatika-antolaketa. Beraz, arrazoi ona daukagu uste izateko giza kontzeptuen berezko oinarriaren parte dela.

Adibide horiek erakusten dute, baita ere, hizkuntzak objektuen kokapena adierazten duela ez espazio absolutuaren arabera, baizik eta beti hondo batean kokatutako irudien arabera. Hondo hori espazioko eremu bat da, eta erreferentzia-objektuek (horien artean lirateke hiztuna eta entzulea) mugatzen dute haren antolaketa. Logika formalaren arabera, hizkuntzak funtzionatzeko duen bide naturala izan liteke hori edo ez. Baina, testuinguru psikologikoan, erabat 
naturala da, guztiz bat baitator pertzepzio-sistemetan aurkitutako irudi-hondo antolaketarekin; eta, hortaz, aplikazio naturalez hornitzen ditu 7.3 atalean eztabaidatutakoen motako pertzepzio-egiaztatzearen prozeduretan.

\section{Antolatze bera pentsamenduaren eremu abstraktuetan}

Gruberrekin (1965) sortu zen, orobat, I-semantikako bigarren oinarrizko ondorioa; erakutsi zuen espazioko objektu fisikoak deskribatzeko erabili ohi diren gramatika-eredu asko espaziokoak ez diren eremuak deskribatzen dituzten adierazpenetan ere agertzen direla.

Ondorio hori erakusten dute (14)tik (17)ra bitarteko perpaus taldeek. Lehenengo adibideak, (14a)k, oraintxe aztertutako irudi-hondo antolaketa erakusten du; multzo osoak eredu gramatikal eta kontzeptual handiagoak azaltzen ditu, zeinen barruan kokatuta dagoen eredu jakin hori. Jarri arreta, batez ere, letra etzanean dauden hitzen bidez adierazitako parekoetan.

(14) Espazio-kokapena eta -mugimendua

a. The messenger is in Istanbul.

(Kokapena)

[Mezularia Istanbulen dago.]

b. The messenger went from Paris to Istanbul.

[Mezularia Paristik Istanbula joan zen.] (Kokapena aldatzea)

c. The gang kept the messenger in Istanbul. (Eragindako egoera [Gaizkile taldeak Istanbulen eduki zuen mezularia.] estatikoa)

(15) Jabetza

a. The money is Fred's.

(Jabetza)

[Fredena da dirua.]

b. The inheritance finally went to Fred. [Fredi eman zioten azkenean ondoretasuna.]

c. Fred kept the money.

[Fredek gorde zuen dirua.]

(Jabetza aldatzea)

(Eragindako egoera estatikoa)

(16) Propietateak egoztea

a. The light is red.

[Semaforoa gorrian dago.]

b. The light went/changed from green to red.

[Semaforoa berdetik gorrira aldatu zen.]

c. The cop kept the light red.

[Poliziak semaforoa gorrian eduki zuen.]

(Propietate arrunta)

(Propietatea aldatzea)

(Eragindako egoera

estatikoa) 
(17) Ekintzak programatzea

a. The meeting is on Monday.

(Programa arrunta) [Astelehenean da bilera.]

b. The meeting was changed from Tuesday to Monday. (Programa aldatzea) [Asteartetik astelehenera aldatu zuten bilera.]

c. The chairman kept the meeting on Monday. (Eragindako egoera [Zuzendariak astelehenean mantendu zuen bilera.] estatikoa)

Talde horietako bakoitzak be [izan, egon] aditza duen perpaus bat, go [joan] duen bat eta keep [gorde, eduki, mantendu] duen bat dauzka. Be preposizio batekin azaltzen denean ((14a)n eta (17a)n bezala), preposizio bera ager daiteke keepekin; be preposiziorik gabe azaltzen bada ((15a)n eta (16a)n bezala), baita keep ere. Go eta change, berriz, from [-tik] eta to [-ra] preposizioekin batera azaldu ohi dira.

Ez dago adierazitako egoeren izaera fisikotik datorren arrazoirik eredu horientzat. Jabetza aldatzeak ez dakar nahitaez kokapena aldatzea: etxe bat edo akzioak saltzeak ez du eskatzen inola ere mugimendurik. Objektu baten koloreak ez du zerikusirik kokagunearekin eta jabearekin. Bilera edo bidaia baterako zehaztutako ordua jartzeak ez du inola ere harreman nabarmenik beste hirurekin.

Maila abstraktuago batean, ordea, parekoak dira perpausen lau taldeen esanahiak.

1. «Be» perpaus guztiek gauza-egoera batzuk deskribatzen dituzte, non ezaugarriren bat egozten zaion perpauseko subjektuari: eremu batean kokatzea (14)n, norbaitena izatea (15)en, ezaugarri bat izatea (16)n, eta zehaztutako ordua izatea (17)n.

2. «Go/change» perpaus guztiek perpausaren subjektuari eragiten dion aldaketa bat deskribatzen dute, eta dagokion «be» perpausak egozten dion ezaugarria izatera iristen da. Aldaketaren hasieran subjektuak duen ezaugarria «from»en ondotik datorren sintagmaren bidez deskribatzen da, eta aldaketaren bukaeran duena «to»ren ondotik datorren sintagmaren bidez.

3. «Keep» perpaus guztiek deskribatzen dute perpauseko subjektuak eragiten duela perpauseko objektuak dagokion «be» perpausak egotzitako ezaugarria izatea, eta ezaugarri horrek denbora-tarte batean irauten du.

Beste hitz batzuetan esanda, multzo horien arteko hizkuntz parekotasunak azpian dagoen kontzeptu-parekotasuna erakusten du. Beraz, ez dira kasualitatez agertzen behin eta berriz item lexikal berak (14)-(17)n.

Ideia hau dago kontzeptu-parekotasunaren atzean: gauzak (14)-(17)ko izenburuen gisako familia zabaletan edo «eremu semantikoetan» sartzen di- 
ren gisa uler daitezkeelako ezaugarriak. Eremu batean, «be» perpausek ezaugarri arruntak adierazten dituzte; hala nola, leku jakin batean egotea, pertsona jakin batena izatea, kolore jakin batekoa izatea edo ordu jakin baterako programatua izatea. Baina, horrez gain, edozein eremuri aplika dakizkiokeen kontzeptu konplexuak ditu kontzeptu-sistemak. Horien artean dira (1) ezaugarri batetik besterako aldaketa («go/change» perpausak) eta (2) zerbaitek beste zerbaitek denbora-tarte batean ezaugarri jakina izanaraztea («keep» perpausak). Sistema abstraktu bera eremu semantiko askotan (eta beharbada guztietan) azaltzen denez, komenigarria da hizkuntzarentzat hitz berak erabiltzea eremu batetik bestera aldatzean.

Izan ere, up [gora] eta down [behera] edo high [handi, altu] eta low [txiki, baxu] kontrako linealen arabera adierazten da balioen dimentsio bakarreko mailan aldatzen den ia edozein ezaugarri. Zenbakiek (eta, beraz, prezioek, pisuek eta hozberoek) gora eta behera egiten dute, gradu militarrek gora eta behera egiten dute, musika-eskalako tonuek gora eta behera egiten dute, eta baita norberaren umoreak ere. Haatik, ezaguna den bezala, denbora-kontzeptuak orokortze horren salbuespen partzialak dira: ia hizkuntza guztietan, espaziorako ere aplikatzen diren hitzen bidez adierazten dira; baina, up [gora] eta downen [behera] ordez, aurretik atzerako continuum bat erabiltzen dute, esaterako, ingelesez before [aurretik] eta after [ondoren].

Antzeko eredu gramatikal eta lexikalak azaltzen dira hizkuntza guztietan. Talmyk (1978, 1985a) eta Langackerrek (1987) funtsean jakintzat eman, eta kontzeptu-egituraren teoriak garatzen dituzte haien inguruan. Lakoff eta Johnsonek (1980) eta Lakoffek $(1987,1990)$ argudiatzen dute metaforen sistema handi baten parte direla, zeina hizkuntzaren bidez adierazitako kontzeptu-egituran dagoen txertatuta banatu ezinik. Gainera, argudiatzen dute metaforaren hedadura handiak ezinezko egiten duela teoria semantiko bat «egia literal» nozio sinplistan oinarritzea, eta ezinezko metafora ez-egibaldintzazko gisa eta, ondorioz, bazterreko gisa hartzea.

Jackendoffek (1983; 1992, 3. kapitulua) eta Jackendoff eta Aaronek (1991) bereizketa zehatzago baten alde egiten dute, nahiz eta metaforaren nonahikotasuna onartu. Metaforaren tradizioko nozioa adierazpen sortzaile, berriei aplikatzen zaie; askotan ageriko talka semantikoa izaten du, hizketa koloretsuago bihurtzeko erabiltzen dena. Lakoff eta bestek metafora terminoa zabaltzen dute terminoen eremu semantiko batetik besterako zeinahi hedatzetara. Hala ere, (14)-(17)n azaldutako parekoek ez dute talka semantikorik, eta bide horiexek bakarrik daude eskura ingelesean hizpide diren kontzeptuak adierazteko. Beraz, ez dira metaforikoak ohiko zentzuan. Jackendoffek argudiatzen du, ondorioz, azpiko eredu abstraktu zehatzen multzo bat dutela kontzeptu-egituraren primitiboek, (14)-(17)koen gisako eremu semantiko desberdin askori aplika dakiekeena. Eredu horiek dira oinarrizko makineria, edozein alorretan pentsamendu konplexua formulatzea eta oinarrizko 
inplikazio logikoak egitea onartzen duena. Espazio-eremuaren ageriko nagusitasuna, beraz, dagokie (1) bere eboluzioko nagusitasunari eta (2) pertzepzioarekin duen lotura estuari. (Horrek ez ditu galarazten, gainera, metaforaren maila altuagoko prozesuak).

Dena den, erabakita dago eztabaida hori, bat datoz I-semantikako pentsamenduaren eskola nagusi guztiak (Fodor izan ezik): (14)-(17)n erakutsitako parekotasun linguistikoek funtsezko parekotasunak islatzen dituzte perpaus horiek adierazten dituzten kontzeptuetan; eta, horren bitartez, giza egitura kontzeptualaren oinarrizko antolaketa erakusten dute.

\section{Erreferentziaren teoriaren kidea I-semantikan}

Gogoan izan, I-semantikan, hizkuntzak erreferentzia egin diezaiekeen entitateak ez direla, inola ere, «munduan» dauden entitateak, baizik eta munduan dauden entitateak gizakiek hura ulertzen duten gisa. Baieztapen hori hobeto uler daiteke orain, azken hiru atalen argitan. Hartu, esaterako, (17b), The meeting was changed from Tuesday to Monday [Bilera asteartetik astelehenera aldatu zuten]. The cat sat on the mat [Katua alfonbraren gainean zegoen] perpausak ez bezala, ez du adierazten hauteman daitekeen ezer. Jendearen gogoetan soilik gertatzen den zerbait deskribatzen du; haien geroko jokaera aldatzen du. Izan ere, Monday [astelehen] moduko izena jarritako denboraldien ideia asmakuntza kontzeptuala da garbi —ez dago pertzepzioz nabarmena den ezer Mondayren mugen inguruan-. Alabaina, gizakiek errealitatea bizi dute, dudarik gabe, astelehenak eta planak balitu bezala; eta Monday terminoa hartzen da erreferentzia egiteko.

Oraindik erakargarriagoa da jabetzaren kasua. Zerbait zurea bada, ez da nirea; eta ezagutza horrek asko baldintzatzen du gure jokabidea. Bizi dugun errealitatearen zati garrantzitsua da zer norena den. Hala eta guztiz ere, jabetza-predikatuak pertzepzio-oinarri txikia du. Erabat kontzeptualak diren nozioak, esaterako eskubideak eta betebeharrak, ditu objektu baten erabilera potentzialaren gainetik.

Kategorizaziora itzuliz, ez dago ezer munduan muga zorrotza eskatzen duenik gorriaren eta laranjaren artean, eta ez dago ezer munduan igotzea zorrotz bereizten duenik beste era bateko mugimenduetatik. Gizakiak munduko xehetasunak kategoriatan sailkatzeko duen beharrak sortzen ditu banaketa horiek. Laburbilduz, hizkuntzaren bidez adierazitako kontzeptuen alderdi asko gogo-eratze hutsak dira. Halarik ere, ez dira fikziozkoak edo zentzugabeak — gizakientzat mundua den eraren parte dira-.

Objektu eta ekintza fisikoek joera dute pertzepzio-lotura sendoak izateko mundu «errelarekin»; gizarte-eratzeek ez hainbeste. Dena den, ez da semantikaren auzia per se nola dauden antolatuta pertzepzio-lotura horiek; pertzep- 
zio-teoriaren parte da. Erlazionatutako kontzeptuen arteko barneko inferentzia-printzipioak dira semantikaren parte.

Beisboleko strike kontzeptua da adibide baliagarri bat. Strikek beisbol jokoan duen rolak harrarazten du gertaera jakin bat striketzat; strike bat halako hiru izaten dira batedunak huts egiten duenean. Gisa honetako gauzak dira hautematez froga daitezkeen baldintzak: bateatzaileak, jomuga den pilota jotzen saiatu, eta huts egin duen, edo bateatzailea jotzen saiatu ez den jomuga-pilota «strike eremutik» pasatu ote den. Pertzepzio-teoriarentzako gaia da zehaztea epaileak nola epaitzen duen pilota nora joan den eta bateatzaileak zer egin duen. Gertaera fisikoaren esanahi guztiak — beisbol jokoaren azpigertaera egoki gisa gertatzen den, eta nola hartzen den jokoaren bilakaerankontzeptualak dira erabat. Nolanahi ere, erreferentzialki erabil daiteke, argi eta garbi, strike terminoa. Strikeak identifikatu, zenbatu eta kuantifika daitezke; eta ez hori bakarrik, milioika pertsona arduratzen da haietaz.

Dirudienez, pertzepzio- eta kontzeptu-baldintzen halako konbinazioak hedatuta daude giza kontzeptuetan (ikus Carey 1985, Keil 1989 eztabaidarako). Bereziki, badirudi kontzeptu teoriko eta zientifiko askok striken ezaugarri orokorrak dituztela; antolaketa logiko-kontzeptual landua dute, pertzepzio-behatzeen aukera sakabanatu batean oinarrituta dagoena.

Gertakari logiko eta matematikoen kasua ematen da, batzuetan, erreferentziaren hurbiltze horren kontra. Gertakari abstraktuak diren arren, egiazkotzat hartzen dira askotan, giza behatzaileak gorabehera. (Hori da, esaterako, Katzek (1981) I-semantika arbuiatzean ematen duen argudio nagusietakoa, hurbiltze platondarraren alde). I-semantikan, ordea, alderantzizko bihurtzen da arazoa: zer dute gizakiek (1) gertakari logiko eta matematikoak ulertzea ahalbidetzen diena eta (2) egiazko direla sinetsarazten diena, giza behatzaileak gorabehera? Ez dago garbi oraindik; eztabaida interesgarriak dituzte Macnamarak (1986) eta Lakoffek (1987).

Gai bat geratzen da, batzuek semantikaren edozein teoriarentzako gai nagusitzat dutena; bereziki, esanahiak buruan kokatzen dituenarentzat. Intentzionalitatearen gaia da: nola izan daitekeen esanahiduna garunaren barruko bereizketa formalen multzo bat, nola izan daitezkeen «munduari» buruzkoak. Dena dela, hurbiltze I-semantikoan, ohikotik desberdin samar interpretatzen da gai hori. I-semantikak baieztatzen du, nahiz eta behatzailearengandik kanpoko gisa bizi dugun «mundua», zentzu hertsian, behatzaileek mundua interpretzearengatik soilik diren entitatez beteta dagoela —oraintsu aipatutako adibideak bezala-. Ondorioz, gogoaren errepresentazioak esanahidunak izatea ez zaio egotzi behar buruko sinboloen eta aurrez baden, aurrekategorizatutako «mundu errealaren» arteko ezein erlazio sinpleri. Nahiko irtenbide desberdinak proposatzen dituzte Fodorrek (1990), Jackendoffek (1987) eta Lakoffek (1987); horien zirriborro laburrek ere urrutiegira eramango lukete saiakera hau. 
Gai hori konpontzen den moduan konpontzen dela ere, garrantzitsua da ohartzea aurre egin behar diola gizakiak hizkuntza nola ulertzen duen azaldu nahi duen edozein teoriari. Hurbiltze E-semantiko bati (edo hurbiltze «erdi-Esemantiko» bati) eusteak, halako zailtasunik ez duelako, atzeratu besterik ez du egiten auzia, konpondu gabe.

Aldi berean, intentzionalitateari buruzko doktrina sendo bat ez egoteak ez du eragotzi I-semantikako hainbat eskolak hizkuntzak adierazten dituen kontzeptuen izaerari buruzko eta kontzeptu horiek giza psikologia eta bilakaerarekin duten loturari buruzko ondorio sakonen aukera bat sortzea. Ondorio horiek hartu behar lukete beste tradizio batzuetako semantikarien arreta.

\section{Erreferentzia bibliografikoak}

Armstrong, S. L.; Gleitman, L. \& Gleitman, H. (1983), «On what some concepts might not be». Cognition 13: 263-308.

Bach, K. \& Harnish, R. W. (1979), Linguistic Communication and Speech Acts. Cambrigde, MA: MIT Press.

Berlin, B. \& Kay, P. (1969), Basic Color Terms: Their Universality and Evolution. Berkeley: University of California Press.

Bierwisch, M. (1967), «Some Semantic universals of German adjectivals». Foundations of Language 3: 1-36.

Bierwisch, M. (1969), «On certain problems of semantic representation». Foundations of Language 5: 153-184.

Bierwisch, M. (1981), «Basic issues in the development of word meaning». In W. Deutsch (arg.), The Child's Construction of Language. London, New York: Academic Press, 341-387.

Bierwisch, M. (1982), «Formal and lexical semantics». Linguistische Berichte 80: 3-17.

Bierwisch, M. (1992), Where is What and What is Where? Manuscript, Berlin: MaxPlanck-Arbeitsgruppe für Strukturelle Grammatik.

Bierwisch, M. \& Lang, E. (arg.) (1989), Dimensional Adjectives: Grammatical Structure and Conceptual Interpretatio. Berlin: Springer-Verlag.

Bloom, P. (1994), «Possible Names: the role of syntactic-semantic mapping in the acquisition of nominals». Lingua 92: 297-329.

Bowerman, M. (1974), «Learning the structure of causative verbs: A study in the relationship of cognitive, semantic, and syntactic development». Papers and Reports on Child Language Development 8. Stanford: Stanford University Department of Linguistics.

Bowerman, M. (1978), «Systematizing semantic knowledge: Changes over time in the child's organization of word meaning». Child Development 49: 977-987.

Bowerman, M. (1989), «Learning a semantic system: What role do cognitive predispositions play?». In M. L. Rice \& R. C. Schiefenbusch (arg.), The Teachability of Language. Baltimore: Paul H. Brooks.

Brown, R. (1973), A First Language: The Early Stages. Cambridge, MA: Harvard University Press.

Brugman, C. (1981), Story of Over. Bloomington, Indiana: Indiana University Linguistics Club. 
Carey, S. (1985), Conceptual Change in Childhood. Cambridge: MA: MIT Press.

Choi, S. \& Bowerman, M. (1991), «Learning to express motion events in English and Korean: The influence of language specific lexicalization patterns». Cognition 41: 83-121.

Chomsky, N. (1965), Aspects of Theory of Syntax. Cambridge, MA: MIT Press.

Chomsky, N. (1986), Knowledge of Language: Its Nature, Origin and Use. New York: Praeger Publishers.

Clark, H. (1973), «Space, time, semantics, and the child». In T. E. Moore (arg.), Cognitive Development and the Acquisition of Language. New York: Academic Press, 27-64.

Clark, H. \& Chase, W. (1972), «On the process of comparing sentences against pictures». Cognitive Psychology 3: 472-517.

Coleman, L. \& Kai, P. (1981), «Prototype semantics: The English verb lie». Language 57: $26-44$.

Fauconnier (1985), Mental Spaces. Cambridge, MA: MIT Press.

Fillmore, C. J. (1982), «Towards a descriptive framework for spatial deixis». In R. Jarvella \& W. Klein (arg.), Speech, Place, and Action. New York: Wiley, 31-59.

Fodor, J. A. (1975), The Language of Thought. Cambridge, MA: Harvard University Press.

Fodor, J. A. (1990), A Theory of Content and Other Essays. Cambridge, MA: MIT Press.

Fodor, J. A.; Bever, T. \& Garrett, M. (1974), The Psychology of Language. New York: McGraw-Hill.

Fodor, J. A.; Garrett, M.; Walker, E. \& Parkes, C. (1980), «Against definitions». Cognition 8: 263-367.

Gruber, J. S. (1965), Studies in Lexical Relations. PhD Dissertation, MIT, Cambridge, MA. Hemen ere argitaratua: J. Gruber (1976), Lexical Structures in Syntax and Semantics. Amsterdam: North-Holland.

Herskovits, A. (1986), Language and Spatial Cognition: An Interdisciplinary Study of the Prepositions in English. Cambridge: Cambridge University Press.

Jackendoff, R. (1976), «Toward and explanatory semantic representation». Linguistic Inquiry 7: 89-150.

Jackendoff, R. (1978), «Grammar as evidence for conceptual structure». In M. Halle, J. Bresnam \& G. Miller (arg.), Linguistics Theory and Psychological Reality. Cambridge, MA: MIT Press, 201-228.

Jackendoff, R. (1981), «On Katz's autonomous semantics». Language 57: 425-435.

Jackendoff, R. (1983), Semantics and cognition. Cambridge, MA: MIT Press.

Jackendoff, R. (1987), Consciousness and the Computational Mind. Cambridge, MA: MIT Press.

Jackendoff, R. (1990), Semantic Structures. Cambridge, MA: MIT Press.

Jackendoff, R. (1992), Languages of the Mind. Cambridge, MA: MIT Press.

Jackendoff, R. \& Aaron, D. (1991), Lakoff \& Turner (1989)ren liburu-kritika. Language 67: 320-338

Katz, J. J. (1966), The Philosophy of Language. New York: Harper and Row.

Katz, J. J. (1972), Semantic Theory. New York: Harper and Row.

Katz, J. J. (1981), Language and Other Abstract Objects. Totowa, NJ: Rowman and Littlefield.

Katz, J. J \& Fodor, J. A. (1963), «The structure of a semantic theory». Language 39: 170-210.

Katz, N.; Baker, E. \& Macnamara, J. (1974), «»What's in a name? A study of how children learn common and proper names». Child Development 45: 469-473.

Keil, F. C. (1979), Semantic and Conceptual Development: An ontological Perspective. Cambridge, MA: Harvard University Press. 
Keil, F. C. (1989), Concepts, Kinds, and Cognitive Development. Cambrigde, MA: MIT Press.

Lakoff, G. (1987), Women, Fire, and Dangerous Things. Chicago: University of Chicago Press.

Lakoff, G. (1990), «The Invariance hypothesis: Is abstract reasoning based on image-schemas?». Cognitive Linguistics 1: 39-74.

Lakoff, G. \& Johnson, M. (1980), Metaphors We Live By. Chicago, IL: University of Chicago Press.

Lakoff, G. \& Turner, M. (1989), More Than Cool Reason: A Field Guide to Poetic Metaphor. Chicago: University of Chicago Press.

Landau, B. \& Gleitman, L. (1985), Language and Experience: Evidence from the Blind Child. Cambridge: Harvard University Press.

Landau, B. \& Jackendoff, R. (1993), «'What' and 'where' in spatial language and spatial cognition». Behavioral and Brain Sciences 16: 217-238.

Langacker, R. (1987), Foundations of Cognitive Grammar, Vol. 1. Stanford: Stanford University Press.

Langacker, R. (1991), Foundations of Cognitive Grammar, Vol. 2. Stanford: Stanford University Press.

Lerdahl, F. \& Jackendoff, R. (1983), A Generative Theory of Tonal Music. Cambrigde, MA: MIT Press.

Levelt, W. (1984), «Some perceptual limitations in talking about space». In A. van Doorn, W. van de Grind \& J. Koenderink (arg.), Limits in Perception. Utrecht: Coronet Books.

Levinson, S. (1992), Language and Cognition: The Cognitive Consequences of Spatial Description in Guugu Yimithirr. Working Paper No. 13, Cognitive Anthropology Group. Nijmegen: Max Institute for Psycholinguistics.

Liberman, A. \& Studdert-Kennedy, M. (1977), «Phonetic Perception». In R. Held, H. Leibowitz \& H.-L. Teuber (arg.), Handbook of Sensory Physiology, Vol. VIII, Perception. Heidelberg: Springer-Verlag.

Macnamara, J. (1982), Names for Things. Cambrigde, MA: MIT Press.

Macnamara, J. (1986), A Border Dispute. Cambrigde, MA: MIT Press.

Markman, E. (1989), Categorization and Naming in Children. Cambrigde, MA: MIT Press.

Marr, D. (1982), Vision. San Francisco: Freeman.

Miller, G. \& Johnson-Laird, P. (1976), Language and Perception. Cambridge, MA: Harvard University Press.

Millikan, R. (1984), Language, Thought, and Other Biological Categories. Cambridge, MA: MIT Press.

Minsky, M. (1975), «A framework of representing knowledge». In P. H. Winston (arg.), The Psychology of Computer Vision. New York: McGraw-Hill.

Nikanne, U. (1990), Zones and Tiers: A Study of Thematic Structure. Helsinki: Suomalaisen Kirjallisuuden Seura.

Partee, B. H. (1993), «Semantic structures and semantic properties». In E. Reuland \& W. Abraham (arg.), Knowledge and Language, Vol II: Lexical and Conceptual Structure. Dordrecht: Kluwer, 7-29.

Piaget, J. (1970), Genetic Epistemology. New York: Columbia University Press.

Pinker, S. (1984), Language Learnability and Language Development. Cambridge, MA: Harvard University Press.

Pinker, S. (1989), Learnability and Cognition: The Acquisition of Argument Structure. Cambrigde, MA: MIT Press. 
Pustejovsky, J. (1991), «The generative lexicon». Computational Linguistics 17: 409-441.

Putnam, H. (1975), «The meaning of meaning». In K. Gunderson (arg.), Language, Mind, and Knowledge: Minnesota Studies in the Philosophy of Science. Minneapolis: University of Minnesota Press, 131-193. Hemen berrargitaratua: 1975, Mind, Language and Reality: Philosophical Papers, Vol. 2. Cambridge: Cambridge University Press.

Rosch, E. (1973), «On the internal structure of perceptual and semantic categories». In T. E. Moore (arg.), Cognitive Development and the Acquisition of Language. New York: Academic Press, 111-144.

Rosch, E. (1975), «Cognitive reference points». Cognitive Psychology 7: 532-547.

Rosch, E. (1978), «Principles of categorization». In E. Rosch \& B. Lloyd (arg.), Cognition and Categorization. Hillsdale, NJ: Erlbaum, 27-48.

Rosch, E. \& Mervis, C. (1975), «Family resemblances: studies in the internal structure of categories». Cognitive Psychology 7: 573-605.

Rosch, E.; Mervis, C.; Gray, W.; Johnson, D. \& Boyes-Braem, P. (1976), «Basic objects in natural categories». Cognitive Psychology 8: 382-439.

Schank, R. (1973), "Identification of conceptualizations underlying natural language». In R. Schank \& K. Colby (arg.), Computer Models of Thought and Language. San Francisco: Freeman, 187-248.

Schank, R. \& Abelson, R. (1975), Scripts, Plans, Goals, and Knowledge. Hillsdale, NJ: Erlbaum.

Talmy, L. (1978), «The relation of grammar to cognition». In D. Waltz (arg.), Proceedings of TINLAP-2: Theoretical Issues in Natural Language Processing. Urbana: University of Illinois.

Talmy, L. (1980), «Lexicalization patterns: Semantic structure in lexical forms». In T. Shopen (arg.), Language Typology and Syntactic Description: Grammatical Categories and the Lexicon (vol. 3). Cambridge: Cambridge University Press, 57-149.

Talmy, L. (1983), «How language structures space». In H. Pick \& L. Acredolo (arg.) Spatial Orientation: Theory, Research, and Application. New York: Plenum Press.

Talmy, L. (1985), «Force dynamics in language and thought». In Papers From the Twenty-First Regional Meeting, Chicago Linguistic Society. University of Chicago, Chicago, IL. Baita hemen ere: Cognitive Science 12: 49-100 (1988).

Vandeloise, C. (1986), L'espace en Français. Paris: Editions du Seuil. Ingelesezko itzulpena: Spatial Prepositions. Chicago: University of Chicago Press (1991).

Weinreich, U. (1966), «Explorations in semantic theory». In T. Sebeok (arg.), Current Trends in Linguistics, Vol. 3. The Hague: Mouton. Hemen berrargitaratua: U. Weinreich (1980), On Semantics. Philadelphia: University of Pennsylvania Press, 99-201.

Wertheimer, M. (1923), «Laws of organization in perceptual forms». In W. D. Ellis (arg.), A Source Book of Gestalt Psychology. London: Routledge and Kegan Paul, 71-88.

Wierzbicka, A. (1980), Lingua Mentalis. Sydney: Academic Press.

Wierzbicka, A. (1985), Lexicography and Conceptual Analysis. Ann Arbor: Karoma.

Wierzbicka, A. (1987), English Speech Act Verbs: A Semantic Dictionary. New York: Academic Press.

Wierzbicka, A. (1988), The Semantics of Grammar. Amsterdam: Benjamins.

Wittgenstein, (1953), Philosophical Investigations. Oxford: Blackwell.

Zwarts, J. \& Verkuyl, H. (1994), «An algebra of conceptual structure: An investigation into Jackendoff's conceptual semantics». Linguistics and Philosophy 17: 1-28. 
